\title{
ANALISIS POTENSI NANOPARTIKEL SENG OKSIDA SEBAGAI TERAPI ALTERNATIF TERHADAP UROPATHOGENIC ESCHERICHIA COLI PENYEBAB INFEKSISALURAN KEMIH
}

\author{
Kelvin Kohar,' Grady Krisandi,' Stephanie Amabella Prayogo' \\ 'Pendidikan Dokter, Fakultas Kedokteran, Universitas Indonesia, Jakarta
}

Korespondensi:

Kelvin Kohar

Email author:

kelvin.kohar.KK@gmail.com

Riwayat Artikel

Diterima: 1 Februari 2021 Selesai revisi: 1 Juli 2021

DOI :

10.53366/jimki.v9i1.278

\section{ABSTRAK}

Pendahuluan: Hingga saat ini, infeksi saluran kemih (ISK) masih menjadi masalah kesehatan utama dunia yang menyerang 150 juta orang per tahunnya. Bakteri Uropathogenic Eschericia coli (UPEC) bertanggung jawab atas lebih dari $80 \%$ keseluruhan kasus tersebut. Dalam menginfeksi saluran kemih, UPEC didukung dengan berbagai faktor virulensi yang turut berperan dalam mengakibatkan resistensi terhadap antibiotik sebagai tatalaksana farmakologis utama ISK. Kemajuan dalam perkembangan teknologi nanopartikel menunjukkan bahwa nanopartikel seng oksida memiliki aktivitas antimikroba. Oleh karena itu, kajian literatur ini dibuat untuk membahas potensi nanopartikel seng oksida dalam menangani ISK akibat UPEC serta membantu mewujudkan tujuan pembangunan berkelanjutan nomor 3 , yaitu menjamin kehidupan yang sehat dan mendorong kesejahteraan bagi semua orang di segala usia.

Metode: Artikel ini disusun berdasarkan metode literature review. Berbagai pusat data daring dengan menggunakan beberapa kata kunci digunakan untuk pencarian literatur. Kriteria inklusi kemudian digunakan untuk menyaring literatur. Hasil akhir pencarian mendapatkan 30 literatur.

Pembahasan: Nanopartikel seng oksida dapat disintesis dari ekstrak tumbuhan Aloe vera. Pada konsentrasi yang sangat kecil, $0,3 \mu \mathrm{g} / \mathrm{ml}$, nanopartikel ini memiliki efek antiadhesi dengan menurunkan ekspresi gen flu dan $\mathrm{fimH}$, sebagai faktor virulensi UPEC. Efektivitas dan keamanan penggunaan nanopartikel pada konsentrasi ini juga telah dibuktikan secara in vitro. Selain itu, nanopartikel seng oksida dengan konsentrasi tinggi juga dapat berperan sebagai antibiofilm dan antibakteri.

Simpulan: Nanopartikel seng oksida memiliki sifat anti-adhesi, antibakteri, dan antibiofilm yang menjanjikan. Keamanan nanopartikel seng oksida telah dibuktikan secara in vitro dan in vivo. Kedua hal ini menunjukkan potensi besar nanopartikel seng oksida untuk menjadi alternatif tatalaksana pada ISK akibat UPEC.

Kata Kunci: Infeksi saluran kemih, Nanopartikel seng oksida, Uropatogenik Escherichia coli 


\title{
The Analysis of Zinc Oxide Nanoparticles as a Potential Alternative Therapy for Urinary Tract Infection Caused by Uropathogenic Escherichia coli
}

\begin{abstract}
Background: To date, urinary tract infection (UTI) is still becoming the world's major health problem that infected 150 million people annually. Uropathogenic Escherichia coli (UPEC) is the most common cause, accounted for more than $80 \%$ of total cases. UPEC infection mechanism is supported by many virulence factors owned that contribute in causing antibiotic resistance. Antibiotics are currently used as main pharmacologic therapy for UTI; therefore, treatment failures often occur. The advancement of nanoparticles technology reveals an antimicrobial activity in zinc oxide nanoparticles. Hence, this literature review is written to discuss the potential of zinc oxide nanoparticles as an alternative as well as to help reaching the third 2030 sustainable development goals.

Methods: This article was written using the literature review method. We did literature searching by using some keywords in several databases. Inclusion criterias were used to filterthe study. The final result yielded 30 studies related to the topic.

Discussion: Zinc oxide nanoparticles can be synthesized from Aloe vera plant extraction. In small concentration, $0.3 \mu \mathrm{g} / \mathrm{ml}$, nanoparticles show an antiadhesion effect by reducing flu andfimH gene expression as UPEC's virulence factors. The effectivity and safety of nanoparticles in this concentration have also been proven in vitro. Furthermore, in high concentration, these nanoparticles can act as antibiofilm and antibacterial.

Conclusion: Zinc oxide nanoparticle has a promising characteristic of antiadhesion, antibacterial and antibiofilm. The safety have also been proven in vitro and in vivo. Both resultsshow a huge zinc oxide nanoparticles potential as an alternative treatment of UTI caused by UPEC.
\end{abstract}

Keywords: Urinary tract infection, Zinc oxide nanoparticle, Uropathogenic Escherichia coli. 


\section{PENDAHULUAN}

Infeksi saluran kemih (ISK) merupakan infeksi bakteri pada kandung kemih yang paling umum terjadi di dunia dengan menjangkit 150 juta orang per tahunnya. ${ }^{[1]}$ Berdasarkan Survei Demografi dan Kesehatan Republik Indonesia pada tahun 2014, terdapat setidaknya 90-100 kasus pada setiap 100.000 penduduk per tahun atau sama dengan 180.000 kasus baru setiap tahunnya. ${ }^{[2]}$ ISK lebih banyak ditemukan pada pasien berusia 16 hingga 35 tahun. Penelitian menunjukkan sebanyak 40-60\% perempuan pernah mengalami ISK paling tidak sekali dalam hidupnya. ${ }^{[1]}$

Secara klinis, terdapat dua jenis ISK, yaitu uncomplicated ISK dan complicated ISK. Uncomplicated ISK biasanya terjadi pada orang yang sehat dan tidak mengalami abnormalitas baik secara struktur maupun neurologis pada saluran kemihnya. ${ }^{[3]}$ Berbeda dengan uncomplicated ISK, kejadian complicated ISK terasosiasi dengan kondisi lain, seperti abnormalitas struktural, fungsi, atau penyakit pada saluran urogenital. Keadaan ini menyebabkan complicated ISK memiliki kemungkinan prognosis yang lebih buruk. ${ }^{[4]}$ Jenis infeksi ini juga dapat diklasifikasikan berdasarkan lokasinya, menjadi ISK bagian bawah dan ISK

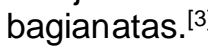

ISK disebabkan oleh bakteri patogen yang tidak hanya bakteri gram negatif, tetapi juga bakteri gram positif. Bakteri patogen penyebab ISK ,antara lain Uropathogenic Escherichia coli (UPEC), Klebsiella pneumoniae, Staphylococcus saprophyticus, Enterococcus faecalis, group B Streptococcus (GBS), Proteus mirabilis, Pseudomonas aeruginosa,

Staphylococcus aureus dan Candida spp. dengan tingkat prevalensi yang berbeda pada uncomplicated ISK dan complicated ISK. Namun, terdapat kesamaan jenis bakteri patogen sebagai penyebab tersering dari kedua macam ISK, yaitu Uropathogenic Escherichia coli (UPEC) dengan persentase $65-75 \% .{ }^{[3]}$ Selain itu, berdasarkan etiologinya, UPEC juga menjadi penyebab dari $80-90 \%$ ISK komunitas (community acquired). ${ }^{[5]}$
UPEC merupakan bakteri gram negatif yang mengalami perubahan status dari flora normal dan bakteri komensal dalam usus menjadi bakteri patogen ekstraintestinal. E. coli dari usus dapat masuk ke sistem saluran kemih dan berkoloni melalui uretra, area periuretral, dan area vaginal. ${ }^{\left[{ }^{6]}\right.}$ Kemampuan UPEC untuk menginfeksi saluran kemih tidak lepas dari berbagai faktor virulensi yang mendukung proses infeksi. Faktor virulensi penting Escherichia coli dikelompokkan menjadi dua kelompok, yaitu faktor pada permukaan bakteri dan faktor yang disekresi. Faktor yang berada pada permukaan bakteri, antara lain Pili tipe 1 dan $P, \quad$ flagellum, kapsul lipopolisakarida, dan protein membran luar lainnya. Pili sendiri berperan dalam proses adhesi UPEC pada permukaan sel inang, invasi jaringan, pembentukan biofilm, dan induksisitokin. ${ }^{[7,8]}$

Sebagai tatalaksana dari ISK, berbagai antibiotik telah digunakan sesuai dengan diagnosis spesifik infeksi saluran kemih yang dialami pasien. Penggunaan antibiotik yang banyak rupanya telah meningkatkan resistensi UPEC secara global. Peningkatan ini berkorelasi dengan penggunaan antibiotik dalam terapi empiris yang berlebihan, tanpa adanya pengecekan kerentanan antibiotik yang mengakibatkan pengobatan yang tidak efektif. Wagenlehner dkk juga telah melakukan studi terkait hal ini dan menunjukkan bahwa $56 \%$ pasien rawat inap diberikan antimikroba. $\mathrm{Di}$ antara mereka, $46 \%$ diberikan sebagai terapi antibiotik profilaksis, 26\% diberikan pada pasien ISK, $21 \%$ diberikan pada pasien yang dicurigai menderita ISK, dan $7 \%$ sisanya diberikan akibat infeksi lain. Hal ini menunjukkan adanya penggunaan antibiotik yang sangat luas, terutama pada penggunaan fluorokuinolon, sefalosporin, dan penisilin. ${ }^{[6]}$ Adanya resistensi antibiotik ini juga salah satu penyebab kegagalan pengobatan ISK. ${ }^{[9]}$

Kemajuan era sekarang ini sudahmulai memanfaatkan nanopartikel sebagai penanganan berbagai penyakit karena ukurannya yang kecil dan efektivitasnya yang baik. Nanopartikel adalah kelompok atom yang memiliki 
ukuran 1-100 nanometer. Salah satu nanopartikel yang berpotensi dalam menangani ISK akibat UPEC adalah nanopartikel seng oksida. Nanopartikel seng oksida memiliki properti katalis, magnet, optik, dan biologis, seperti aktivitas antimikroba. Ukurannya yang kecil dan luas permukaannya yang besar membuat nanopartikel menjadi materi yang dapat meningkatkan aktivitas antimikroba dan properti lainnya. ${ }^{[10]}$

Oleh karena itu, kajian literatur ini dibuat untuk membahas potensi nanopartikel seng oksida dalam menangani ISK akibat UPEC serta membantu mewujudkan tujuan pembangunan berkelanjutan nomor 3 , yaitu menjamin kehidupan yang sehat dan mendorong kesejahteraan bagi semua orang di segala usia.

\section{METODE}

Metode yang digunakan dalam penulisan tinjauan pustaka ini adalah pencarian dan tinjauan literatur dari berbagai pusat data daring dan search engine. Pusat data daring yang digunakan untuk mencari literatur adalah PubMed, SCOPUS, dan Springer, sedangkan search engine yang digunakan adalah Google dan Google Scholar. Pencarian dilakukan dengan menggunakan beberapa kata kunci, yaitu Uropathogenic Escherichia coli, nanoparticle $\mathrm{ZnO}$, urinary tract infection, safety, efficacy, mechanism, dan pathogenesis. Literatur yang masuk dalam tinjauan pustaka ini adalah pustaka dengan tahun terbit dari 2011-2020, berbahasa Indonesia atau Inggris, dan relevan dengan yang ingin ditinjau. Dari hasil pencarian literatur, ditemukan 30 literatur relevan dan digunakan untuktinjauan pustaka ini.

\section{PEMBAHASAN}

\subsection{Patogenesis Infeksi Saluran} Kemih (ISK) Akibat Uropathogenic Escherichiacoli (UPEC)

Patogenesis ISK merupakan proses kompleks yang melibatkan beberapa faktor, baik dari host, lingkungan, maupun faktor virulensi bakteri. ${ }^{[11]}$ Dalam keadaan normal, saluran kemih seharusnya berada dalam keadaan steril. Penelitian menunjukkan bahwa terdapat dua mekanisme yang diperkirakan mampu menyebabkan penyakit ini, yaitu rute ascending dan rute hematogen. ${ }^{[12]}$ Rute ascending yang disebabkan oleh flora E. coli pada feses menjadi penyebab paling sering dari infeksi. Dari feses, bakteri ini menyebar melalui perineum, vagina, serta periuretra untuk mengolonisasi saluran kemih bagian bawah. ${ }^{[5,12]} \mathrm{Di}$ vesica urinaria, mikroorganisme tersebut akan mengalami perlekatan di permukaan dan berinteraksi dengan sistem pertahanan epitel organ. ${ }^{[5]}$ Kolonisasi dapat terjadi karena kemampuan bakteri untukmengekspresikan berbagai faktor virulensi, seperti adhesin, toksin, LPS, siderofor, dan flagella. ${ }^{[5,11]}$

Sebenarnya, sel epitelium pada lumen vesika urinaria bersifat sebagai sawar dan memiliki mekanisme antibakteri yang baik. Pembuangan urin juga diperkirakan mampu mengeluarkan sebagian bakteri. Namun, mikroorganisme E. coli memiliki faktor virulensi adhesin menyerupai Pili yang mampu berikatan kuat dengan sel epitel vesica urinaria tersebut. ${ }^{[5]}$ Pili tipe 1 diperkirakan dapat meningkatkan kemampuan bertahan hidup bakteri, menstimulasi inflamasi pada mukosa, serta mendorong terjadinya proses invasi dan pertumbuhan biofilm. Pili ini mampu berikatan pada urothelial mannosylated glycoprotein uroplakin la dan IIla menggunakan subunit adhesin fimH pada ujung Pili. Ikatan tersebut menyebabkan terjadinya fosforilasi yang akan menstimulasi jalur pensinyalan yang diperkirakan terlibat dalam proses invasi dan apoptosis sel epitel. Peristiwa ini dapat dibatasi dengan adanya mekanisme pertahanan tubuh host melalui ekskresi ginjal, yaitu protein Tamm-Horsfall (THP) yang disekresikan pada urin manusia. THP dapat bereaksi dengan reseptor $\mathrm{fimH}$ yang akan menghancurkan interaksi antara bakteri dan sel epitel. Selain itu, juga terdapat Pili $P$ yang memiliki ekspresi adhesin Pap G, yang dapat berikatan dengan sel ginjal. Akibatnya, terjadi pelepasan seramid yang berfungsi sebagai agonis Toll-like receptor 4 (TLR4) sehingga menyebabkan inflamasi lokal terkait ISK. Adhesin lainnya, yaitu Pili S dan Pili 
$1 c$ juga dapat berikatan dengan sel epitel pada ginjal dan saluran kemih. Pili $S$ mampu memfasilitasi penyebaran bakteri ke dalam jaringan host. Jenis adhesin lainnya, yaitu afimbrilliar (afa) dan fimbrial Dr juga diperkirakan terkait dengan mekanisme terjadinya ISK. ${ }^{[13]}$ TosA adhesin dan Iha adhesin yang merupakan bagian dari afa berperan sebagai adhesi yang dapat meningkatkan kolonisasi UPEC. Selain itu, FdeC adhesin juga berperan dalam kolonisasi sel epitel kandung kemih dan ginjal. $^{[13,14]}$

Faktor virulensi jenis lainnya, yaitu LPS juga berperan penting dalam proses patogenesis ISK. LPS diperkirakan mampu berikatan dengan TLR4 yang diekspresikan di sel epitel urinaria dan berperan dalam proses inflamasi. Selain itu, mekanisme inflamasi juga diperkirakan dapat terjadi melalui mediasi protein yang berikatan dengan LPS, serta molekul aksesoris lain, seperti CD14, MD2, dan domain TIR. ${ }^{[13]}$ UPEC juga menghasilkan toksin alpha hemolysin (HlyA) yang menyebabkan terjadinya lisis sel darah merah serta menstimulasi pelepasan spesi oksigen reaktif, seperti anion superoksida dan hidrogen peroksida. Semua peristiwa ini menyebabkan terjadinya inflamasi dan kerusakan jaringan pada sel host. ${ }^{[11]}$

Selama kolonisasi, bakteri juga mampu membentuk biofilm untuk melindungi diri dari antibiotik dan berkontribusi terhadap mekanisme resistensi. ${ }^{[5,11]}$ Pada infeksi akut, eksfoliasi dapat terjadi akibat apoptosis terkait caspase 3 dan 8 dari sel epitel terinfeksi. Mekanisme eksfoliasi akibat aliran urin tidak selalu menjadi strategi pertahanan host yang baik karena dapat menyebabkan penyebaran bakteri ke jaringan yang lebih dalam. Lebih jauh lagi, bakteri juga mampu untuk mengalami migrasi ke arah ginjal dan membentuk kolonisasi di organ tersebut. Akibatnya, dapat terjadi kerusakan jaringan serta peningkatan risiko untuk bakteremia. ${ }^{[5]}$

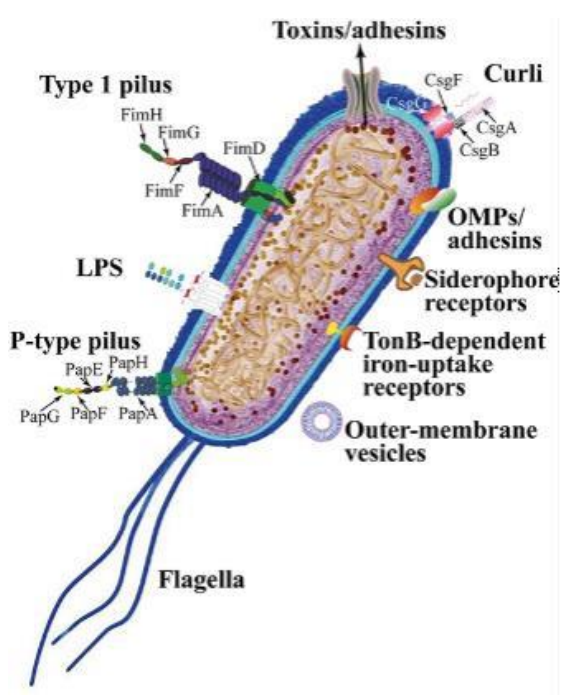

Gambar 1. Struktur dan faktor virulensi bakteri E. Coli[i[]

\section{Sumber Nanopartikel ZnO}

Nanopartikel seng oksida ( $\mathrm{ZnO})$ dapat diekstraksi melalui metode fisika, kimiawi, dan biologis. Cara fisika dan kimiawi jarang digunakan karena memiliki berbagai kelemahan, termasuk penggunaan peralatan yang mahal serta potensi kerusakan lingkungan yang tinggi. ${ }^{[15]}$ Biosintesis dapat dipilih sebagai alternatif karena mampu menghasilkan zat dengan karakteristik baik dan tetap ramah lingkungan. Sintesis $\mathrm{ZnO}$ dapat diperoleh dari ekstrak berbagai tanaman, seperti Berberis aristata, Passiflora caerulea, Mimosa pudica, termasuk juga Aloe vera. $^{[6,17,18]}$

Aloe vera atau dikenal sebagai lidah buaya merupakan tumbuhan yang tidak jarang dijumpai di Indonesia. Nanopartikel zat ini didapatkan melalui pengolahan daridaun Aloe vera dengan metode yang cukup mudah. Awalnya, daun harus dicuci terlebih dahulu dengan air distilasi agar terbebas dari kontaminasi. Selanjutnya, daun dikupas dan dipisahkan dari gel yang berada di bawahnya. Daun tersebut akan dihomogenkan bersama air distilasi menggunakan mortar dan pestle, serta disaring untuk membentuk ekstrak. Proses biosintesis dilakukan dengan penambahan larutan zinc sulphate ( $\mathrm{ZnSO} 4.7 \mathrm{H} 20)$ dan natrium hidroksida $(\mathrm{NaOH})$ pada ekstrak tersebut. Pada akhirnya, nanopartikel hasil sintesis akan disentrifugasi selama 10 menit dengan kecepatan 10.000 rpm. Sebagai 
upaya melakukan konfirmasi terhadap keberhasilan sintesis nanopartikel tersebut, analisis UV-Vis spectroscopy dapat digunakan. Jika berhasil, UV-Vis spectroscopy akan menunjukkan hasil absorpsi sebesar 200-300 nm. ${ }^{[16,19]}$ Ketika dianalisis menggunakan $X$-ray diffraction (XRD), nanopartikel $\mathrm{ZnO}$ dari ekstrak Aloe vera menunjukkan gambaran partikel berbentuk heksagonal. ${ }^{[16]}$

Studi lain menunjukkan bahwa penggunaan metode dan larutan berbeda pada ekstrak yang sama dapat mengubah bentuk nanopartikel. Pada studi tersebut, daun Aloe vera yang telah dipotong didihkan bersama dengan air deionisasiuntuk membentuk ekstrak. Selain itu, larutan yang digunakan untuk proses sintesis nanopartikel $\mathrm{ZnO}$ adalah larutan zinc nitrate. Sentrifugasi juga dilakukan dalam kecepatan yang berbeda yaitu 3000 rpm. Pada akhirnya, analisis menggunakan XRD menunjukkan adanya gambaran partikel berbentuk spheric. ${ }^{[20]}$ Kedua bentuk nanopartikel ini diperkirakan memiliki kemampuan dalam menghambat proses infeksi dari UPEC. ${ }^{[10,16]}$

\subsection{Mekanisme Kerja Nanopartikel SengOksida}

Nanopartikel seng oksida dapat menjadi alternatif dalam menangani ISK melalui beberapa mekanisme. Pertama, nanopartikel ini ditemukan dapat menghambat pembentukan biofilm bakteri. Shakerimoghaddam, et al. menunjukkanbahwa terdapat inhibisi total pembentukanbiofilm pada $20 \%$ dari isolat yang diuji, $14 \%$ inhibisi menengah, dan $16 \%$ mengalami inhibisi lemah pada pemberian nanopartikel seng oksida pada konsentrasi minimal nanopartikel dapat menghambat pertumbuhan isolat.[21] Hasil ini juga didukung studi Kaur, et al. yang menampilkan adanya visualisasi yang jelas efek antibiofilm ini. Studi ini juga menjelaskan lebih lanjut bahwa aktivitas antibiofilm nanopartikel lebih efektif apabilaberada pada materi dasar gelas dan logam (aluminium) daripada plastik. ${ }^{[23]}$

Efek inhibisi pembentukan biofilm ini juga dipengaruhi oleh konsentrasi nanopartikel yang digunakan. ${ }^{[21]}$ Pada pemberian konsentrasi setengah dari konsentrasi inhibisi minimum pertumbuhan isolat menampilkan adanya penurunan ekspresi gen flu. Selain itu, gen $\mathrm{fimH}$ juga ditemukan mengalami penghambatan dan didukung oleh studi dari Jamalam, et al. pula. ${ }^{[22,23]}$ Gen flu dan fimH merupakan faktor virulensi dominan pada UPEC. Gen flu berperan dalam memproduksi antigen 43, yaitu protein permukaan pada Escherichia coli yang bertanggung jawab dalam autoagregasi dan flokulasi, sedangkan Gen fimH mengode Pili tipe 1 yang merupakan faktor virulensi paling sering $(80 \%)$ ditemukan pada UPEC. UPEC yang mengekspresikan fimH dapat menempel pada reseptor glikoprotein monomannose dan trimannose di sel epitel saluran kemih sehingga proses kolonisasi bakteri bisa terjadi.[22] Oleh karena itu, nanopartikel seng oksida berperan menghambat langkah awal UPEC dalam menginfeksi, yaitu adhesi ireversibel. Bahkan Jamalan, et al. juga menyebutkan bahwa netralisasi protein $\mathrm{fimH}$ dapat secara signifikan menghalangi kolonisasi UPEC pada saluran kemih. ${ }^{[23]}$ Akan tetapi, pemberian konsentrasi sebesar setengah dari konsentrasi minimal nanopartikel yang dapat menghambat pertumbuhan isolat menunjukkan hasil bahwa pada konsentrasi tersebut tidak bisa menginhibisi pembentukan biofilm secara sempurna, hanya berupa inhibisi lemah. ${ }^{[21,22]}$

Selain sifatnya dalam mencegah adhesi dan pembentukan biofilm, nanopartikel seng oksida juga ditemukan oleh Kaur, et al. memiliki efek antibakteri diduga berasal dari kemampuan nanopartikel seng oksida dalam mempenetrasi membran sel bakteri sehingga mengubah permeabilitas membrannya. Perubahan ini menyebabkan keluarnya asam nukleat bakteri dari sel yang sejalan dengan penemuan studi yang menunjukkan pengeluaran asam nukleat yang cukup banyak. Studi ini juga menyebutkan adanya kemungkinan efek antibakteri yang baik nanopartikel seng oksida diakibatkan oleh luas permukaan nanopartikel yang besar. ${ }^{[24]}$ Penelitian oleh Torabi juga 
menampilkan adanya efek bakteriostatis dan kemampuan merusak sel membran hingga membunuh sel bakteri. $^{[10]}$

\subsection{Efektivitas Nanopartikel Seng Oksida Terhadap Uropathogenic Escherichia coli}

Efektivitas nanopartikel seng oksida telah diuji pada beberapa percobaanterhadap UPEC. Dua studi terpublikasi yang dilakukan oleh Shakerimoghaddam $\mathrm{A}$, et al. menunjukkan bahwa nanopartikel $\mathrm{ZnO}$ dapat berperan sebagai anti-adhesi, anti-biofilm, dan anti-bakteri terhadap UPEC. Hal ini dibuktikan dengan penurunan ekspresi gen $\mathrm{fimH}$ yang signifikan pada berbagai isolat UPEC. Selain itu, sifat antibiofilm dan antibakteri juga dibuktikan pada UPEC saat tonsentrasi inhibisi minimum mencapai $2500 \mu \mathrm{g} / \mathrm{ml}$. Tidak hanya itu, penurunan ekspresi gen flu yang mengekspresikan adhesin antigen 43 untuk pembentukan biofilm juga terjadi. ${ }^{[21,22,25]} \mathrm{Di}$ lain hal, studi oleh Torabi menunjukkan konsentrasi inhibisi dan bakterisidal minimum bakteri hanya sekitar 40 hingga 200 $\mu \mathrm{g} / \mathrm{ml}$ untuk nanopartikel $\mathrm{ZnO}$ berbentuk spherical dan berukuran 20 $\mathrm{nm}$. Torabi menunjukkanbahwa bentuk dan ukuran nanopartikelZnO berperan dalam konsentrasi inhibisi dan bakterisidal minimum terhadap UPEC.

Namun, studi-studi sebelumnya tidak menjelaskan bentuk dan ukuran nanopartikel ZnO yang digunakan. ${ }^{[10]}$ Studi lain oleh Jamalan $M$, et al. juga mendukung temuan mengenai kemampuan nanopartikel $\mathrm{ZnO}$ sebagai anti-adhesi terhadap UPEC. Pada konsentrasi hanya $0,3 \mu \mathrm{g} / \mathrm{ml}$, studi membuktikan penurunan adhesi yang cukup signifikan dari 28,77 hingga 44,71\%.[23] Temuan-temuan ini menunjukkan potensi besar nanopartikel $\mathrm{ZnO}$ sebagai anti-adhesi, antibakteri, dan antibiofilm untuk menangani ISK akibat UPEC.

\subsection{Keamanan Nanopartikel Seng Oksida}

Keamanan penggunaan

nanopartikel seng oksida telah diuji pada berbagai studi. Studi oleh Hong TK, et al. membuktikan toksisitas nanopartikel seng oksida meningkat seiring peningkatan konsentrasi yang diberikan secara in vitro maupun in vivo. Studi in vitro menunjukkan toksisitas pada konsentrasi $100 \mu \mathrm{g} / \mathrm{ml}$ yang dibuktikan dengan penurunan viabilitas sel dan peningkatan spesies oksigen reaktif (ROS) intrasel. Studi in vivo menunjukkan hal yang konsisten bahwa konsentrasi $100 \mu \mathrm{g} / \mathrm{ml}$ yang dibuktikan dengan perubahan histopatologis yang bervariasi tergantung jalur administrasi nanopartikel seng oksida yang digunakan. Walaupun bervariasi, secara keseluruhan konsentrasi 100 $\mu \mathrm{g} / \mathrm{ml}$ menunjukkan perubahan histopatologis berupa apoptosis pada jaringan hati, paru, dan ginjal. Pada dosis rendah yang diujikan menggunakan $1 \mu \mathrm{g} / \mathrm{ml}$ dan $10 \mu \mathrm{g} / \mathrm{ml}$ menunjukkan hasil yang aman secara in vitro maupun in vivo. Studi in vitro membuktikan bahwa konsentrasi tersebut tidak menyebabkan penurunan viabilitas sel secara signifikan, tidak menyebabkan peningkatan ROS intrasel signifikan, serta tidak terjadi peningkatan ekspresi sitokin proinflamasi. Tidak hanya secara in vitro, tetapi studi secara in vivo juga menunjukkan adanya perubahan histopatologis yang tidak signifikan berupainflamasi ringan pada ginjal dan hati. ${ }^{26]}$ Temuan ini juga didukung oleh studi Uzar NK, et al. yang menunjukkan peningkatan toksisitas pada sel ginjal manusia seiring dengan peningkatan konsentrasi yang digunakan. Studi ini menguji konsentrasi nanopartikel $\mathrm{ZnO}$ dari $25 \mu \mathrm{g} / \mathrm{ml}$ hingga $100 \mu \mathrm{g} / \mathrm{ml}$ dengan $100 \mu \mathrm{g} / \mathrm{ml}$ menunjukkan penurunan viabilitas sel tertinggi dan signifikan. Hasil uji efek genotoksik nanopartikel $\mathrm{ZnO}$ dari studi ini menunjukkan bahwa efek genotoksik mulai muncul pada konsentrasi $12,5 \mu \mathrm{g} / \mathrm{ml}^{[27]}$ Studi lain oleh Sahu D, et al. mendukung temuan bahwa peningkatan toksisitas terjadi seiring dengan peningkatan konsentrasi nanopartikel ZnO. Konsentrasi $5 \mu \mathrm{g} / \mathrm{ml}$ yang diuji tidak menunjukkan efek sitotoksik yang signifikan dibuktikan dengan tidak terjadinya penurunan viabilitas sel yang signifikan; tidak menyebabkan perubahan DNA sel; tidak menyebabkan perubahan histopatologis signifikan, tidak menyebabkan peningkatan kadar ROS 
intrasel, serta tidak menyebabkan penurunan kadar glutation intrasel yang merupakan penanda utama progresi apoptosis. Kadar ROS intrasel juga dibuktikan meningkat signifikan mulai dari konsentrasi nanopartikel $\mathrm{ZnO} 50$ $\mu \mathrm{g} / \mathrm{ml} .{ }^{[28]}$ Berbagai temuan pada studi menunjukkan bahwa konsentrasi nanopartikel $\mathrm{ZnO}$ hingga $10 \mu \mathrm{g} / \mathrm{ml}$ tidak menunjukkan toksisitas signifikan baik dari segi sitotoksisitas maupun genotoksisitas sehingga pada kasus ISK akibat UPEC yang telah terbukti penggunaan konsentrasi nanopartikel ZnOyang tidak melebihi $10 \mu \mathrm{g} / \mathrm{ml}$ masih tergolong aman untuk digunakan. ${ }^{[26-28]}$ Dari temuan ini, konsentrasi antiadhesi tergolong aman dan tidak menimbulkan toksisitas karena hanya dengan konsentrasi $\quad 0,3 \quad \mu \mathrm{g} / \mathrm{ml}$ dapat menghasilkan efek antiadhesi yang signifikan.

Berbagai temuan sebelumnya menemukan bahwa peningkatan toksisitas terjadi seiring dengan peningkatan konsentrasi nanopartikel $\mathrm{ZnO}$ yang digunakan. Penjelasan mengenai peningkatan konsentrasi nanopartikel $\mathrm{ZnO}$ yang menyebabkan toksisitas adalah kelarutan nanopartikel $\mathrm{ZnO}$ yang rendah sehingga memerlukan konsentrasi tinggi agar dapat diserap oleh sel-sel dalam jumlah cukup banyak yang menyebabkan toksisitas. Terlebih lagi, berbagai macam jalur administrasi juga berpengaruh terhadap bioavailabilitas nanopartikel $\mathrm{ZnO}$ dalam tubuh sehingga menimbulkan kemungkinan jalur administrasi tertentu menyebabkan toksisitas walaupun tidak terjadi pada jalur administrasi lain. Berbagai studi in vivo telah menunjukkan bahwa jalur administrasi secara inhalasi terbukti menjadi jalur paling bahaya, sedangkan kulit menjadi jalur masuk yang paling aman. ${ }^{[29]}$ Selain itu, United States Food and Drug Administration (US FDA) juga telah menjamin keamanan penggunaan nanopartikel $\mathrm{ZnO}$ untuk patogenpatogen tubuh, salah satunya $E$. coli. ${ }^{[30]}$ Walaupun demikian, dosis yang tepat perlu diuji lebih lanjut dengan uji klinis untuk memastikan keamanan nanopartikel $\mathrm{ZnO}$, terutama mengenai efek antibakteri dan antibiofilm.

\section{KESIMPULAN}

Nanopartikel seng oksida memiliki potensi sebagai antiadhesi dalam patogenesis UPEC dengan keamanan dan efektivitas yang menjanjikan. Berbagai penelitian menunjukkan bahwa nanopartikel jenis ini mampu menghambat ekspresi gen fimH dan flu pada UPEC yang merupakan faktor virulensi utama dalam menyebabkan infeksi saluran kemih. Terlebih lagi, efek antibiofilm dan antibakteri diidentifikasi pada penggunaan konsentrasi yang lebih tinggi. Akan tetapi, belum ada studi yang memastikan keamanan nanopartikel seng oksida untuk potensi antibiofilm dan antibakteri ini.

Pada akhirnya, melalui kajian literatur ini, nanopartikel seng oksida diharapkan dapat lebih dikembangkan ke depannya atas potensinya yang menjanjikan dalam menjadi alternatif yang lebih efektif untuk menangani ISK akibat UPEC. Jika berhasil, maka nanopartikel seng oksida dapat menjadi solusi pengobatan utama ISK yang dapat menggantikan antibiotik, mengingat tingginya angka resistensi saat ini. Hal ini juga sejalan dengan tujuan pembangunan berkelanjutan nomor 3, yaitu menjamin kehidupan yang sehat dan mendorong kesejahteraan bagi semua orang di segalausia.

\section{SARAN}

Studi lebih lanjut diperlukan untuk memastikan keamanan nanopartikel seng oksida yang memiliki potensi antibiofilm dan antibakteri ini.

\section{DAFTAR PUSTAKA}

1. Bono MJ, Reygaert WC. Urinary tract infection [Internet]. Treasure Island (FL): StatPearls Publishing; 2020 Jan [Updated 2020 Nov 21; Cited 2020 Dec 2]. Available from: https://www.ncbi.nlm.nih.gov/books /N BK470195/

2. Departemen Kesehatan Republik Indonesia (Depkes RI). 2014. Survei Demografi dan Kesehatan Indonesia.Depkes RI: Jakarta.

3. Mireles ALF, Walker JN, Caparon $M$, Hultgren SJ. Urinary tract infections: epidemiology, mechanisms of action and treatment options. Nat Rev Microbiol. 2015 Apr 8;13(5):26984.

4. Tan CW, Chlebicki MP. Urinary tract infections in adults. Singapore 
Med J. 2016 Sep;57(9):485-90.

5. Terlizzi ME, Gribaudo G, Maffei ME. Uropathogenic Eschericia coli (UPEC) infections: Virulence factors, bladder responses, antibiotic, and non- antibiotic antimicrobial strategies. Front Microbiol. 2017 Aug 15;8:1-23.

6. Kot B. Antibiotic resistance among uropathogenic Escherichia coli. Pol J Microbiol. 2019 Dec 5;68(4):40315.

7. Shah C, Baral R, Bartaula B, Shrestha LB. Virulence factors of uropathogenic Escherichia coli (UPEC) and correlation with antimicrobial resistance. BMC Microbiol. 2019 Sep 2;19:204.

8. Grabe $M$, Bartoletti $R$, Johansen TEB, Cai T, Cek M, Koves B, et al. Guidelines on urological infections. European Association of Urology; 2015.

9. Haque R, Akter ML, Abdus Salam M. Prevalence and susceptibility of uropathogens: a recent report from a teaching hospital in Bangladesh. BMC Res Notes. 2015;8:416.

10. Torabi LR. The antibacterial effects of $\mathrm{ZnO}$ nanoparticles on patients with urinary tract infection isolated from Alzahra hospital in Isfahan, Iran. J Res Med Sci. 2017;19(11):e10359.

11. Kudinha T. Escherichia coli: Recent advances on physiology, pathogenesis and biotechnological applications. 1st ed. IntechOpen; 2017 Jul 12. Chapter 3, The pathogenesis of Escherichia Coli Urinary Tract Infection.

12. Robino L, Scavone P, Araujo L, Algorta G, Zunino P, Pirez MC, Vignoli $R$. Intracellular bacteria in the pathogenesis of Escherichia coli urinary tract infection in children. Clin Infect Dis. 2014 Dec 1;59(11):e154- 64.

13. Bien J, Sokolova O, Bozko P. Role of uropathogenic Eschericia coli virulence factors in development of urinary tract infection and kidney damage. Int J Nephrol. 2012 Mar 8;2012:1-15.

14. Vigil $P D$, Stapleton $A E$, Johnson JR, Hooton TM, Hodges AP, He Y, Mobley HLT. Presence of putative repeat-in- toxin gene TosA in
Escherichia coli predicts successful colonization of the urinary tract. mBio. 2011 May 3;2(3):e00066-11.

15. Haq ANU, Nadhman A, Ullah I, Mustafa G, Yasinzai M, Khan I. Synthesis approaches of zinc oxide nanoparticles: The dilemma of ecotoxicity. Journal of Nanomaterials. $2017 \quad$ Apr 18;2017:1-14.

16. Rasli NI, BAsri H, Harun Z. Zinc oxide from Aloe vera extract: twolevel factorial screening of biosynthesis parameters. Heliyon. 2020 Jan;6(1):1- 8.

17. Fatimah I, Pradita RY, Nurfalinda A. Plant extract mediated of $\mathrm{ZnO}$ nanoparticles by using ethanol extract of Mimosa pudica leaves and coffee powder. Procedia Engineering. 2016 Jul 12;48:43-8.

18. Santhoshkumar J, Kumar SV, Rajeshkumar S. Synthesis of zinc oxide nanoparticles using plant leaf extract using urinary tract infection pathogen. Resource-Efficient Technologies. 2017 Dec;3(4):45965.

19. Chaudhary A, Kumar N, Kumar R, Salar RK. Antimicrobial activity of zinc oxide nanoparticles synthesized from Aloe vera peel extract. SN Applied Sciences. 2018 Dec 31;1(136):1-9

20. Sangeetha G, Rajeshwari $S$, Venckatesh R. Green synthesis of zinc oxide nanoparticles by aloe barbadensis miller leaf extract: Structure and optical properties. Materials Research Bulletin. 2011 Aug 26;46:2560-6.

21. Shakerimoghaddam A, Ghaemi EA, Jamalli A. Zinc oxide nanoparticle reduced biofilm formation and antigen 43 expressions in uropathogenic Escherichia coli. Iran J Basic Med Sci. 2017;20(4):451-6.

22. Shakerimoghaddam A, Ghaemi EA, Jamalli A. Effects Of Zno Nanoparticles on Initial Adhesion and fimH Gene Expression Level of Uropathogenic Eschercia coli. J Clin Basic Res. 2017;1(3):0-0.

23. Jamalan $M$, Davoodi $H$, Ghaemi EA, Jamalli A. Anti-adhesive effect of $\mathrm{ZnO}$ nanoparticles against uropathogenic escherichia coli in 
bladder epithelial cell cultures and on fimh gene expression. Jundishapur $\mathrm{J}$ Microbiol. 2019;12(7).

24. Kaur T, Putatunda C, Vyas A, KumarG. Zinc oxide nanoparticles inhibit bacterial biofilm formation via altering cell membrane permeability. Prep Biochem Biotechnol. 2020 Sep 12:1- 11.

25. Ulett GC, Valle J, Beloin C, Sherlock O, Ghigo JM, Schembri MA. Functional analysis of antigen 43 in uropathogenic Escherichia coli reveals a role in long-term persistence in the urinary tract. Infect Immun. 2007;75(7):323344.

26. Hong TK, Tripathy N, Son HJ, Ha $\mathrm{KT}$, Jeong HS, Hahn YB. A comprehensive in vitro and in vivo study of $\mathrm{ZnO}$ nanoparticles toxicity. $J$ Mater Chem B. 2013;1(23):2985-92.

27. Uzar NK, Abudayyak M, Akcay N, Algun G, Özhan G. Zinc oxide nanoparticles induced cyto- and genotoxicity in kidney epithelial cells. Toxicol Mech Methods. 2015;25(4):334-9.

28. Sahu D, Kannan GM, Vijayaraghavan R, Anand T, Khanum F. Nanosized Zinc Oxide Induces Toxicity in Human Lung Cells. ISRN Toxicol. 2013;2013:18.

29. Vandebriel RJ, De Jong WH. A review of mammalian toxicity of $\mathrm{ZnO}$ nanoparticles. Nanotechnol Sci Appl. 2012;5(1):61-71.

30. Sirelkhatim A, Mahmud S, Seeni A, Kaus NHM, Ann LC, Bakhori SKM, et al. Review on zinc oxide nanoparticles: Antibacterial activity and toxicity mechanism. NanoMicro Lett [Internet]. 2015;7(3):219-42 Available from: http://dx.doi.org/10.1007/s40820-

015-0040-x. 